Beyond Philology No. 17/4, 2020

ISSN 1732-1220, eISSN 2451-1498

https://doi.org/10.26881/bp.2020.4.05

\title{
Conference interpreting on the privatemarket: Employment and assignment-related variables
}

\author{
HEATHER ADAMS \\ DAVID BOVY
}

Received 30.11.2020,

received in revised form 29.12.2020,

accepted 29.12.2020.

\begin{abstract}
The benchmark for the study of conference interpreting tends to be the institutional market, in which employment conditions are secure and communicative situations, context and terminology will tend to recur. By contrast, conference interpreters working in the private sector face a range of ever-changing circumstances, negotiating each assignment not only in terms of remuneration but also in terms of all aspects relating to working conditions, thus requiring an increased capacity to adapt on many levels.

This article presents findings from a pilot study that aims to showcase what interpreters working in the private market actually do before their interpreting assignment, over and above the preparation work that all interpreters put in. After a brief contextualization based on both academic and professional literature, this article presents the responses to two questions posed in our study regarding additional tasks carried out before assignments. Our conclusions are relevant to practitioners, trainees and trainers, as they shed light on current professional practice.
\end{abstract}




\title{
Keywords
}

conference interpreting, freelance, private markets, workload

\section{Tłumaczenie konferencyjne w sektorze prywatnym: aspekty związane $z$ zatrudnieniem i realizacją zlecen}

\begin{abstract}
Abstrakt
W badaniach koncentrujacych się na tłumaczeniu konferencyjnym punktem odniesienia jest zazwyczaj rynek instytucjonalny, który charakteryzuje się stabilnymi warunkami zatrudnienia i powtarzalnościa terminologii, kontekstów oraz sytuacji komunikacyjnych. Zupełnie inaczej przedstawia się sytuacja tłumaczy konferencyjnych pracujacych w sektorze prywatnym.

Ulegające ciagłym zmianom warunki realizacji zleceń, a także konieczność każdorazowego negocjowania wysokości wynagrodzenia i zróżnicowanych aspektów świadczonych usług, wymagaja od tej grupy zawodowej dużej elastyczności i zdolności adaptacyjnych.

W niniejszym artykule przedstawiono wyniki badania pilotażowego, którego celem było zidentyfikowanie aktywności podejmowanych przez tłumaczy konferencyjnych w sektorze prywatnym przed realizacja zlecenia, poza typowa dla każdego rynku praca przygotowawcza. Udzielenie odpowiedzi na dwa pytania badawcze poprzedza ukontekstowienie tematyki, przeprowadzone w oparciu o stosowna literaturę przedmiotu. Postawione wnioski sa istotne dla aktywnych zawodowo tłumaczy konferencyjnych, adeptów zawodu i nauczycieli przekładu konferencyjnego, ponieważ rzucaja światło na obecne praktyki rynkowe.
\end{abstract}

\section{Słowa kluczowe}

tłumaczenie konferencyjne, freelance, wolny zawód, sektor prywatny, nakład pracy 


\section{Introduction}

As opposed to dialogue interpreting, which has been practiced for thousands of years, probably ever since human beings first went to war or decided to trade products between societies that spoke different languages, conference interpreting, in both consecutive and simultaneous modes, emerged to answer the need for the spoken translation of institutionalized communication within the formulaic traditions of diplomacy in the $20^{\text {th }}$ century. Conference interpreting was initially born in the realm of international organizations (the League of Nations, UN, EU and the USSR's Comintern (see Baigorri-Jalón 2014 and Chernov 2016), and many continue to associate it with purely institutional settings, particularly in the case of simultaneous interpreting. As an example, Donovan (2017: 91) states that

Conference interpreting is woven into the institutions and structures of the globalized world. As international meetings have multiplied, it has become more commonplace. Most experts or highranking government officials who attend multilateral or international conferences will have listened to a speaker through the headset, hearing the interpreter's voice and understanding the speaker's meaning through interpretation.

However, the demand for conference interpreting "has spread far beyond multilateral diplomacy to virtually any field of activity involving communication and exchange across linguistic boun-daries" (Pöchhacker 2004: 15), and "the skillset of staff interpreters at intergovernmental organizations, parliaments and international tribunals" (Setton and Dawrant 2016: 31), by which they refer to a high level of language proficiency, education and technical skills, as well as professionalism, "is now deployed well beyond the profession's traditional domain in multilateral organizations" (Setton and Dawrant 2016: 373). These same authors highlight the versatility of conference interpreters, bringing to mind Shermet's view (2012: 125) of interpreters as musicians, who have to turn their skill to any number of genres 
and styles, and state that conference interpreters today "must handle a wide spectrum of discourse, from free and colloquial discussion to the reciting of prepared text in rigid and formal registers" (Setton and Dawrant 2016: 31), thus:

In the modern world, conference interpreters need an extended skillset to meet the needs of a much wider variety of settings than the traditional international conference, including parliamentary interpreting, media/broadcast interpreting, diplomatic or high-level business interpreting and, particularly in international tribunals, court interpreting. (Setton and Dawrant 2016: 31)

According to Diriker (2015: 175), nowadays "a significant majority of conference interpreters are freelance interpreters who work in the private market", which leads us to consider the working conditions of these interpreters, and how they compare to those of full-time employees of major international organizations, or of freelancers working for said institutions.

\section{Conference interpreters: working conditions}

Grbic and Pöchhacker (2015) cite three types of variables that most frequently affect the working conditions of interpreters, namely employment conditions, assignment-based factors and input variables. They go on to say that it is the latter, the input factors at the time of interpreting that give rise to the highest levels of occupational stress, and there is no doubt that the process of interpreting itself has received considerable attention from scholars, amongst which Gile's Efforts Model is perhaps the foremost example of the division of labour required between different cognitive tasks in real time on the part of the interpreter (see Gile 2015, for a succinct overview). However, in this article, we are interested in examining the first two in more detail, as, unlike the input variables, which are constant whether interpreters are working in institutional or private settings, these differ by context. In terms of employment conditions, as we pointed out in a previous study (Bovy and Adams 2019), staff 
interpreters are employees of organizations - typically the major international organizations such as the EU and the UN - and are paid according to their seniority within the organization. Their financial and job security is therefore guaranteed (along with other fringe benefits).

In a kind of half-way house position between staff interpreters and freelancers working on the private market, we should also point out that the major international organizations also use freelance conference interpreters on a regular basis, and that in these cases working conditions are negotiated under agreements in place between the organization in question and AIIC (the International Association of Conference Interpreters) (see Diriker 2015: 173 and Grbic and Pöchhacker 2015: 443), so that, although they are self-employed rather than on the payroll, they are much less exposed to the context-related variables than their colleagues working on the private market are.

By contrast, freelance interpreters on the private market are also self-employed, but their income and the stability of their working conditions will depend not only on the legislation in force in their country of residence, which may vary considerably from one country to another, but also, to a large extent, on the client base they are able to build up, and the fees they are able to secure in a fiercely competitive market (although not the thrust of this article, the question of dumping is a common topic of conversation amongst interpreters on the private market the world round).

In addition to the precarious employment situation freelancers live in, they also have to deal with external variables, defined as "those specific properties of the original speeches and their contexts that are out of the interpreters' control, irrespective of their professional competence" (Baigorri-Jalón and Travieso-Rodriguez 2017: 58) that, in a well-oiled international organization that recognizes and relies on the services of its staff interpreters, are taken care of by other members of the organization. As Setton and Dawrant (2016: 31) affirm "[i]n traditional conference interpreting, there is comparatively little need for negotiation of basic conditions, roles and expectations". However, this will not 
be the case for freelance interpreters, who may well have to deal with related variables both before and during interpreting assignments. In this sense, we could cite Kalina's "peri-process framework", including "the conditions in which the interpreting act takes place (data on participants, working languages, team composition, possible relay requirements, documents made available in-conference, time schedules, technical equipment)" (Kalina 2005: 778).

It is interesting to note that Baigorri-Jalon and TraviesoRodriguez's study (2017) among interpreters at the UN seems to indicate that institutional interpreters' working conditions have also been affected by some of these external variables. Of their respondents, $58 \%$ were staff interpreters and $42 \%$, freelancers working at the UN so, although not all "staffers", they would all be working under industry-accepted conditions, as per AIIC. These authors refer to some of the interpreters' concerns as shared in an interpreters' staff meeting, most of which could be placed in the "input" category of working conditions, i.e. factors that come into play when interpreters are actually interpreting, such as the increased speed of delivery of original speeches, as well as accent (due at least in part to the increasing tendency of speakers to give their original speech in English, regardless of their command thereof). Additional factors include the increased participation of non-diplomatic actors from civil society who are "not used to being interpreted and unaware of what is required of them" (Baigorri-Jalón and Travieso-Rodríguez 2017: 67) for interpreters to provide good quality interpretation and the wide range of topics covered. However, one assignment-related concern was mentioned more than once: a lack of provision of speeches before delivery, "especially hard for certain booths that have to provide relay" (Baigorri-Jalón and TraviesoRodriguez 2017: 57), which would appear to indicate that interpreters in these institutional settings were previously used to being given the speeches they would interpret in advance in order to prepare, and that they noted that this was no longer always the case. 


\section{Our study}

Our premise at the outset of this study was that freelance conference interpreters working on the private market would have to deal with a number of external variables that staff interpreters and freelancers working for institutional clients would not. Encouraged by Setton's comment that "in interpreting, practice always came first, informing training and theory" (Setton 2007: 54), we decided to run a small-scale pilot study to see the extent to which our own experiences and those of fellow practitioners were, more or less, widespread. To this end, we drew up a questionnaire (described in Adams and Bovy, forthcoming) covering those factors that seemed to crop up most often, and asked our (controlled) sample to add in any further aspects that they felt were relevant. In this article, we will present the results obtained from the collection of the answers to two particular questions relating firstly to the frequency with which our participants had to negotiate or explain their fees to clients (both confirmed and potential), and secondly, to how often they had to ask (more than once) for documentation in order to prepare for the event and to explain the following aspects pertaining to a particular assignment:

- the difference between simultaneous and consecutive interpreting,

- the general conditions of the interpretation service where travel is involved (fares, travel arrangements, etc.),

- the human resources needed to perform the service (number of interpreters per booth, language combination of the interpreters, etc.),

- the technical requirements to perform the service,

- the concept of "relay" when the assignment calls for relay. 


\section{Methodology}

This initial pilot project, consisting of a preliminary questionnaire with 31 questions for professional interpreters working on the private market, was sent out in February 2019 to 20 interpreters using Google Forms. Our controlled target respondents included participants drawn mainly from our personal database of professional interpreters from all over the world who had participated in the two editions of the WISE Interpreting Workshops that we had also taken part in (2017 and 2019). The reason for controlling the population in this way was mainly to test certain technical aspects/limitations of the Google Forms format, as subsequently proved useful, so that we could make any necessary changes before launching a larger-scale study. Thirteen valid sets of responses were received, constituting $65 \%$ of the population.

\section{Results}

Before presenting the specific findings for this article, we need to describe our sample of participants. The following tables give the breakdown, in \% terms by gender, age, level of training in Translation and/or Interpreting (in this case, some participants marked several options, as would be expected given that they reflect differing levels of higher education - BA, MA, PhD, etc), and years worked as a professional interpreter. In tables 1-4 below, despite the small sample set, we have a good level of variety in terms of age, training and years of professional experience. Although we would in no way claim that this initial group would be representative of freelance interpreters on the private market as a whole, given the limitation in numbers, we were encouraged to see the spread in these fields, which enables us, albeit very tentatively, to say that our results are not directly attributable to, for example, having responses from only either recent graduates or experienced practitioners, for example.

In the case of this last data set, it is worth noting that the largest proportion correspond to those with least experience 
(1-5 years, $30.8 \%)$ and those with most (20+ years, $23.1 \%)$, this latter group tying with participants with 6-10 years of experience working as a professional interpreter on the private market.

Table 1

Participants by gender

\begin{tabular}{|l|c|}
\hline \multicolumn{1}{|c|}{ Gender } & $\%$ \\
\hline Male & $23.1 \%$ \\
\hline Female & $76.9 \%$ \\
\hline I prefer not to answer & - \\
\hline
\end{tabular}

Table 2

Participants by age

\begin{tabular}{|c|c|}
\hline Age range & $\%$ \\
\hline $18-25$ & - \\
\hline $26-35$ & $46.2 \%$ \\
\hline $36-45$ & $23.1 \%$ \\
\hline $46-55$ & $7.7 \%$ \\
\hline $56-65$ & $7.7 \%$ \\
\hline $65+$ & $7.7 \%$ \\
\hline
\end{tabular}

Table 3

Training in translation and/or interpreting

\begin{tabular}{|l|c|}
\hline \multicolumn{1}{|c|}{ Studies in translation and/or interpreting } & $\%$ \\
\hline BA in Translation and Interpreting & $46.2 \%$ \\
\hline MA in Translation and Interpreting & $30.8 \%$ \\
\hline MA in Conference Interpreting & $53.8 \%$ \\
\hline MA in Institutional Translation & $7.7 \%$ \\
\hline PhD in Translation and Interpreting & $7.7 \%$ \\
\hline 1-year interpreting-only postgraduate course & $7.7 \%$ \\
\hline
\end{tabular}




\section{Table 4}

Years of professional experience working as an interpreter

\begin{tabular}{|c|c|}
\hline Years of professional experience & $\%$ \\
\hline $1-5$ & $30.8 \%$ \\
\hline $6-10$ & $23.1 \%$ \\
\hline $11-15$ & $15.4 \%$ \\
\hline $15-20$ & $7.7 \%$ \\
\hline $20+$ & $23.1 \%$ \\
\hline
\end{tabular}

Further to the description of our sample, we will now present the responses to the two questions asked regarding additional tasks that freelance conference interpreters on the private market had to carry out before accepting an assignment.

We have broken them down by the categories given by Grbic and Pöchhacker (2015), taking negotiation of fees to be paid for services rendered as part of employment conditions, and other factors as assignment-related conditions.

\subsection{Employment conditions}

The results given in Table 5 show the frequency with which our participants have to negotiate or explain (we might say justify) the fees they charge, or quote when negotiating an assignment.

\section{Table 5}

Freelancers negotiating or explaining rates/fees

to their clients before an assignment

\begin{tabular}{|l|c|}
\hline \multicolumn{1}{|c|}{$\begin{array}{c}\text { How often do you have to negotiate/explain your } \\
\text { rates/fees to a client? }\end{array}$} & $\%$ \\
\hline Never & $0 \%$ \\
\hline Seldom & $7.7 \%$ \\
\hline Occasionally & $15.4 \%$ \\
\hline Often & $53.8 \%$ \\
\hline Almost always & $23.1 \%$ \\
\hline Always & $0 \%$ \\
\hline
\end{tabular}


In this case we can see that none of our participants reported that they always have to negotiate or explain their fees to clients when contacted for an assignment. However, similarly, all of them have to do so on occasion with varying degrees of frequency (none of them answered "never"). If we take the categories of "often" and "almost always" together $(53.8 \%$ and $23.1 \%$, respectively), we can see that more than $75 \%$ of the sample often have to negotiate or explain their fees, which is something no staff interpreter will have to do. In addition, only $7.7 \%$ (1 person) answered "seldom", and 2 people (15.4\%), occasionally, thereby demonstrating that this additional task is something that has to be undertaken by freelancers more often than not.

\subsection{Assignment-related factors}

In this same vein, we asked our participants to indicate the frequency with which they had to perform a number of additional tasks before the interpreting assignment, as part of the process of negotiating the assignment, to ensure that the technical aspects were fully understood by the client and that the interpreters would be able to prepare the topic and/or presentations sufficiently in advance (see Table 6). The aspects included are common to all conference settings (relay interpreting only as needed) and would, in institutional settings, be automatically taken care of by the conference organizers.

The first thing that strikes us, when we look at this data, is the frequency with which our participants reported having to explain the difference between consecutive and simultaneous interpreting.

As we can see from the results in Table 6, our participants reported that they have to insist by asking more than once for the relevant documentation that will enable them to prepare for their assignment. Only 1 person $(7.7 \%)$ claimed that they never had to, while the remaining $90+\%$ did, at best often, with $60 \%$ having to do so (almost) always. 


\section{Table 6}

Tasks carried out by professional freelance interpreters before an assignment

\begin{tabular}{|c|c|c|c|c|c|c|}
\hline 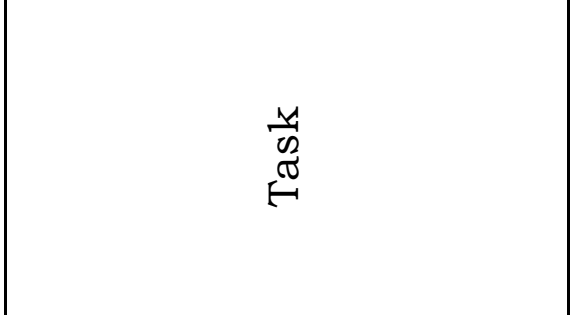 & $\begin{array}{l}\vec{d} \\
\vec{d} \\
z\end{array}$ & 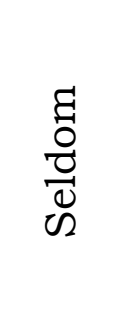 & 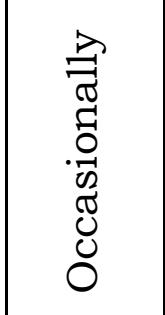 & 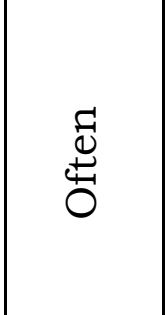 & 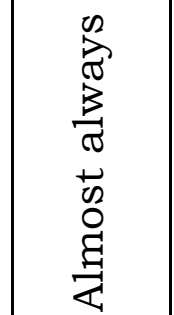 & 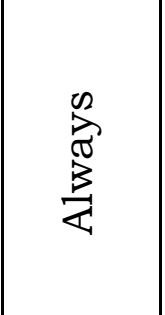 \\
\hline $\begin{array}{l}\text { Explain the difference be- } \\
\text { tween simultaneous and } \\
\text { consecutive interpreting }\end{array}$ & - & - & $38.4 \%$ & $30.8 \%$ & $23.1 \%$ & $7.7 \%$ \\
\hline $\begin{array}{l}\text { Ask (more than once) for } \\
\text { documentation }\end{array}$ & $7.7 \%$ & - & - & $30.8 \%$ & $53.8 \%$ & $7.7 \%$ \\
\hline $\begin{array}{l}\text { Explain the general con- } \\
\text { ditions of the interpreta- } \\
\text { tion service (fares, travel } \\
\text { arrangements. etc.) }\end{array}$ & - & - & $23.1 \%$ & $38.4 \%$ & $23.1 \%$ & $15.4 \%$ \\
\hline $\begin{array}{l}\text { Explain the human re- } \\
\text { sources needed to per- } \\
\text { form the service (number } \\
\text { of interpreters per booth, } \\
\text { language combination of } \\
\text { the interpreters etc.) }\end{array}$ & - & - & $23.1 \%$ & $46.1 \%$ & $23.1 \%$ & $7.7 \%$ \\
\hline $\begin{array}{l}\text { Explain the technical re- } \\
\text { quirements to perform the } \\
\text { service }\end{array}$ & - & - & $38.4 \%$ & $30.8 \%$ & $23.1 \%$ & $7.7 \%$ \\
\hline $\begin{array}{l}\text { Explain the concept } \\
\text { of "relay" when the as- } \\
\text { signment calls for relay }\end{array}$ & - & $7.7 \%$ & $23.1 \%$ & $23.1 \%$ & $38.4 \%$ & $7.7 \%$ \\
\hline
\end{tabular}

Our freelancers also find themselves having to explain the practicalities the routine nuts and bolts associated with the assignment conditions where the interpreters have to travel, such as the fares that apply, having to make travel arrangements and other logistical issues on a regular basis, with more than $75 \%$ of the respondents having to explain these aspects often or more 
frequently, and $15.4 \%$ reporting that they always had to do so. As for explaining the specific human resources needed to carry out an assignment (the number of interpreters per booth, language combination of the interpreters, etc.), this is something that freelance interpreters often have to explain to ensure that clients understand the full implications of the service they require. Thus, we can see that, as in the previous item, none of our respondents reported "never" or "seldom" needing to explain this information to the client, and although $23.1 \%$ only do so occasionally, the majority have to do so often (46.1\%), almost always $(23.1 \%)$ or always $(7.7 \%)$. Similarly, although with a slightly different distribution amongst the degrees of frequency, freelancers often have to explain the technical requirements needed to guarantee that the service can be provided, as well as the details of how relay interpreting works.

In the next question in our pilot study, participants were asked to include any other task(s) performed at least occasionally before an event, in order to see if we should add any further tasks to our final questionnaire. Two of our participants answered, one citing the need to share resources and glossaries with colleagues working at the same event, and the other mentioning the coordination of the team of interpreters, which we know to be a time-consuming task.

\section{Discussion}

Perhaps the most striking element of the results presented in both Tables 5 and 6 is the number of times that none of our respondents marked the option "never" or "seldom". Thus, of these tasks that no staff interpreter would have to negotiate with or explain to a client, almost all fall within the remit of the freelance conference interpreter, generally at the very least "often". This is not limited to their fee explanation and/or negotiation. Staff interpreters receive the notification of the assignments they have to cover and enjoy the back-up of an experienced conference organisers who are used to working with interpreters and technical experts. By contrast, a considerable amount of 
a freelancer's time and energy is taken up ensuring that the client understands the nature of the service she/he is commissioning. These assignment-based variables include explaining the need for specific human and technical resources, insisting on the need for the relevant documentation to be able to prepare the topic and, where possible, the specific presentations that will be given at the event. Freelancers even have to explain the difference between consecutive and simultaneous interpreting, in order to ensure that the client understands what and who is needed. The high levels of frequency reported by our respondents regarding many of these issues reveal the time and energy that freelance interpreters dedicate to negotiating their assignments, and it should be remembered that much of this information will be provided to the client before submitting a budget, precisely to ensure that the budget is fit for purpose, and that there is no guarantee that the freelancer in question will necessarily be awarded the contract, thus adding to the precarious nature of his or her independent status.

\section{References}

Adams, Heather, David Bovy (forthcoming). "Conference interpreting on the private market: a survey".

Baigorri-Jalón, Jesús, Críspulo Travieso Rodríguez (2017). "Interpreting at the United Nations: The impact of external variables. The Interpreters' View". CLINA 3/2: 53-72.

Baigorri-Jalón, Jesús (2014). From Paris to Nuremberg, The Birth of Conference Interpreting (translated by Holly Mikkelson and Barry Olsen). Amsterdam - Philadelphia: John Benjamins.

Bovy, David, Heather Adams (2019). "Características de la interpretación de conferencias en el sector privado". E-Aesla 5: 343-350.

Chernov, Sergei (2016). "At the dawn of simultaneous interpreting in the USSR: Filling some gaps in history". In: Kayoko Takeda, Jesús Baigorri-Jalon (eds.). New Insights in the History of Interpreting. Amsterdam - Philadelphia: John Benjamins, 136-166. 
Diriker, Ebru (2015). "Conference interpreting”. In: Holly Mikkelson, Renée Jourdenais (eds.). The Routledge Handbook of Interpreting. London - New York: Routledge, 171-185.

Donovan, Clare (2017). "The place of the interpreter and interpreting in an institutional Setting". CLINA 3/2: 91-113.

Gile, Daniel (2015). "Effort models". In: Franz Pöchhacker (ed.). Routledge Encyclopedia of Interpreting Studies. London - New York: Routledge, 135-137.

Grbic, Nadia, Franz Pöchhacker (2015). "Working conditions". In: Franz Pöchhacker (ed.). Routledge Encyclopedia of Interpreting Studies. London - New York: Routledge, 441-443.

Pöchhacker, Franz (2004). Introducing Interpreting Studies. London New York: Routledge.

Setton, Robin, Andrew Dawrant (2016). Conference Interpreting A Complete Course. Amsterdam - Philadelphia: John Benjamins.

Shermet, Sheila (2012). "Communication, interpretation and 'Oral Translation'. Contrastive analysis of freelancing vs. working for a large organization". Presentation at Second UN Conference of MOU Universities, University of Mons, Belgium, May 2012, Annex 2, 125-144. Available at <https://www.un.org/dgacm/sites/www.un .org.dgacm/files/Documents_MOU/report_of_the_second_mou_co nference-final.compressed.pdf $>$. Accessed 23.10.2020.

Heather Adams

ORCID ID: 0000-0001-7822-431X

University of Las Palmas de Gran Canaria

Dpt. of Modern Philology, Translation

and Interpreting

$\mathrm{C} /$ Pérez del Toro 1

35003 Las Palmas de Gran Canaria

Spain

heather.adams@ulpgc.es

David Bovy

ORCID ID: 0000-0001-5634-8477

University of Las Palmas de Gran Canaria

Dpt. of Modern Philology, Translation

and Interpreting 
C/Pérez del Toro 1

35003 Las Palmas de Gran Canaria

Spain

david.bovy@ulpgc.es 